\title{
Health status of spring barley grown in the conventional and organic farming systems including conversion
}

\section{Zdrowotność jęczmienia jarego uprawianego w systemie konwencjonalnym i ekologicznym z uwzględnieniem konwersji}

\author{
Tomasz P. Kurowski ${ }^{1}$, Marta Damszel ${ }^{1}$, Urszula Wysocka ${ }^{2}$, Tadeusz Sadowski ${ }^{3}$, Bogumił Rychcik ${ }^{3}$
}

\begin{abstract}
Summary
Spring barley was grown in 2004-2006 on the experimental plots in Bałcyny. The average root rot infection index remained at a similar level and significant differences were modified by crop rotation selection. Symptoms of leaf blotch, net blotch and powdery mildew were recorded on barley leaves. Pyrenophora teres and Rhynchosporium secalis infected cereal leaves more frequently in the conventional system than in the organic system. Conversion period was inhibited influence the intensification of barley leaf dieases. Evaluation of steam base revealed higher severity of fusarium foot rot and eyespot infection in the conventional farming system than in the organic. Fusarium fungi were the largest group of isolates, and destructive pathogen Cochliobolus sativus colonized barley that derived from the organic farming tenfold more frequently, and Aureobasidium and Microdochium were isolated with higher frequency from the barley grown in the conventional system.
\end{abstract}

Key words: spring barley, health status, conventional system, organic system, conversion

\section{Streszczenie}

Jęczmień jary uprawiano w latach 2004-2006 na poletkach doświadczalnych w Bałcynach. Średni indeks porażenia korzeni kształtował się na zbliżonym poziomie, a istotne różnice były modyfikowane doborem płodozmianu. Na liściach jęczmienia odnotowano symptomy rynchosporiozy, plamistości siatkowej oraz mączniaka prawdziwego zbóż i traw. Pyrenophora teres i Rhynchosporium secalis częściej atakowały liście w systemie konwencjonalnym niż ekologicznym. Okres konwersji działał inhibicyjnie na nasilenie chorób liści jęczmienia. Na podstawie źdźbła stwierdzono wyższe nasilenie fuzaryjnej zgorzeli podstawy źdźbła oraz łamliwości źdźbła zbóż i traw w konwencjonalnej uprawie jęczmienia w porównaniu do ekologicznej. Najliczniejszą grupą izolatów były grzyby rodzaju Fusarium, zaś groźny patogen jęczmienia Cochliobolus sativus dziesięciokrotnie częściej zasiedlał jęczmień pochodzący z uprawy ekologicznej, a grzyby rodzaju Aureobasidium i Microdochium z wyższą frekwencją wyosobniano z jęczmienia uprawianego w systemie konwencjonalnym.

Słowa kluczowe: jęczmień jary, zdrowotność, system konwencjonalny, system ekologiczny, konwersja

\footnotetext{
Uniwersytet Warmińsko-Mazurski w Olsztynie

Katedra Fitopatologii i Entomologii

Prawocheńskiego 17, 10-721 Olsztyn

kurowski@uwm.edu.pl

${ }^{2}$ Agencja Rynku Rolnego

Partyzantów 1, 11-041 Olsztyn

${ }^{3}$ Uniwersytet Warmińsko-Mazurski w Olsztynie

Katedra Systemów Rolniczych

Plac Łódzki 3, 10-718 Olsztyn
} 


\section{Wstęp / Introduction}

Jęczmień to zboże, które często jest porażane przez patogeny. Rozprzestrzenianie sprawców chorób i nasilenie ich symptomów uzależnione jest od warunków atmosferycznych oraz czynników agrotechnicznych (Kurowski i wsp. 2005; Weber i wsp. 2005). Zapobieganie negatywnym skutkom chorób jęczmienia jest podstawą zapewnienia dobrej jakości ziarna, co jest szczególnie ważne w systemie ekologicznym, zakładającym zrównoważone funkcjonowanie produkcji roślinnej i jest uzależnione głównie od naturalnych oddziaływań między mikroorganizmami.

Szerokie spektrum wykorzystania jęczmienia jarego pochodzącego z konwencjonalnej i ekologicznej uprawy zbóż uzasadnia zatem stały monitoring fitopatologiczny oraz próbę poszukiwania optymalnych warunków utrzymania dobrej zdrowotności i plonowania tego zboża w obu systemach uprawy.

Celem pracy było porównanie zdrowotności jęczmienia jarego uprawianego w systemie konwencjonalnym i ekologicznym oraz $\mathrm{w}$ okresie konwersji $\mathrm{z}$ uwzględnieniem składu gatunkowego grzybów izolowanych $\mathrm{z}$ podstaw źdźbeł z objawami chorobowymi.

\section{Materiały i metody / Materials and methods}

Jęczmień jary odmiany Atol uprawiano na poletkach doświadczalnych w Bałcynach (53,6 N, 19,85 E) na glebie średnio zwięzłej, kompleksu pszennego dobrego i żytniego bardzo dobrego, według zasad rolnictwa konwencjonalnego i ekologicznego. Dwa lata badań (2004, 2005) stanowiły okres konwersji, a kolejny (2006) był już uprawą w systemie ekologicznym. W systemie tym jęczmień uprawiano w płodozmianie 6-polowym wszechstronnym oraz okopowym, zaś w systemie konwencjonalnym 6-polowym zbożowym i zbożowo-okopowym. W obu systemach uprawy jęczmienia jarego nie stosowano chemicznych środków ochrony roślin, ponadto w uprawie konwencjonalnej zastosowano nawożenie mineralne 30-60 kg N, 60 kg $\mathrm{P}_{2} \mathrm{O}_{5}, 100 \mathrm{~kg} \mathrm{~K} \mathrm{~K}_{2} \mathrm{O}$, zaś w ekologicznej siłę nawozową stanowił przedplon (ziemniak).

Zdrowotność korzeni (BBCH 55) oceniano metoda Łacicowej (1970), liści (BBCH 75) metodą Hinfnera i Pappa (1964), a zdrowotność podstawy źdźbła (BBCH 85) według metody Mackiewicza i Drath (1972). Uzyskane wyniki przedstawiono w postaci indeksu porażenia, obliczonego metodą Towsenda i Heubergera (1943). Istotność różnic oszacowano korzystając z programu Statistica 8, przy użyciu testu Duncana przy poziomie istotności 0,05 .

W celu wyizolowania grzybów będących sprawcami chorób podsuszkowych $\mathrm{z}$ pobranych $\mathrm{z}$ doświadczenia podstaw źdźbeł wykazujących objawy nekroz wycinano $30 \mathrm{~mm}$ odcinki i postępowano zgodnie z metodą Reineckego i Fehrmanna (1979).

\section{Wyniki i dyskusja / Results and discussion}

We wszystkich latach badań, niezależnie od systemu gospodarowania, odnotowano występowanie objawów zgorzeli korzeni, których sprawcami były grzyby rodzaju Fusarium, Rhizoctonia, Cylindrocarpon i Gaeumannonyces. W uprawie jęczmienia, w systemie ekologicznym indeks porażenia wyniósł $13,5 \%$, zaś w systemie konwencjonalnym w pierwszych dwóch latach był wyrównany (11,4\%), a w 2006 roku osiagnął aż 25,7\% badanych organów roślinnych (tab. 1). W płodozmianie 6-polowym zbożowym odnotowano wzrost występowania objawów zgorzeli w kolejnych latach prowadzonego doświadczenia.

Tabela 1. Indeks porażenia korzeni, liści i podstawy źdźbła jęczmienia jarego

Table 1. The infection of roots, leaves and stem base of spring barley

\begin{tabular}{|c|c|c|c|c|c|c|c|}
\hline \multirow{2}{*}{$\begin{array}{l}\text { Choroba - patogen } \\
\text { Disease - pathogen }\end{array}$} & \multirow{2}{*}{$\begin{array}{l}\text { Część rośliny } \\
\text { Part of plant }\end{array}$} & \multirow{2}{*}{$\begin{array}{l}\text { Rok } \\
\text { Year }\end{array}$} & \multirow{2}{*}{\begin{tabular}{|c|} 
Faza \\
rozwojowa \\
Growth stage \\
{$[\mathrm{BBCH}]$}
\end{tabular}} & \multicolumn{3}{|c|}{$\begin{array}{l}\text { System gospodarowania } \\
\text { Farming system }\end{array}$} & \multirow{2}{*}{$\begin{array}{c}\text { NIR } \\
(0,05) \\
\text { LSD } \\
(0.05)\end{array}$} \\
\hline & & & & $\begin{array}{l}\text { ekologiczny } \\
\text { organic }\end{array}$ & $\begin{array}{l}\text { konwencjonalny } \\
\text { conventional }\end{array}$ & $\begin{array}{l}\text { konwersja } \\
\text { conversion }\end{array}$ & \\
\hline 1 & 2 & 3 & 4 & 5 & 6 & 7 & 8 \\
\hline $\begin{array}{l}\text { Zgorzel korzeni } \\
\text { Complex of fungi }\end{array}$ & $\begin{array}{c}\text { korzeń } \\
\text { root }\end{array}$ & $\begin{array}{l}2004 \\
2005 \\
2006\end{array}$ & 55 & $\begin{array}{c}- \\
- \\
13,5\end{array}$ & $\begin{array}{l}11,4 \\
11,4 \\
25,7\end{array}$ & $\begin{array}{r}16,7 \\
8,5 \\
-\end{array}$ & $\begin{array}{l}6,89 \\
2,89 \\
3,87\end{array}$ \\
\hline \multicolumn{4}{|l|}{ Średnio - Mean } & 13,5 & 16,2 & 12,6 & \\
\hline $\begin{array}{l}\text { Rynchosporioza zbóż } \\
\text { Rhynchosporium secalis }\end{array}$ & $\begin{array}{l}\text { liść } \\
\text { leaf }\end{array}$ & $\begin{array}{l}2005 \\
2006\end{array}$ & 75 & $\begin{array}{l}- \\
3,4\end{array}$ & $\begin{array}{l}3,4 \\
5,7\end{array}$ & $\begin{array}{l}1,7 \\
-\end{array}$ & $\begin{array}{l}1,20 \\
\text { r.n. }\end{array}$ \\
\hline \multicolumn{4}{|l|}{ Średnio - Mean } & 3,4 & 4,6 & 1,7 & \\
\hline $\begin{array}{l}\text { Plamistość siatkowa } \\
\text { Pyrenophora teres }\end{array}$ & $\begin{array}{l}\text { liść } \\
\text { leaf }\end{array}$ & $\begin{array}{l}2005 \\
2006\end{array}$ & 75 & $\begin{array}{c}- \\
26,4\end{array}$ & $\begin{array}{l}18,4 \\
35,3\end{array}$ & $\begin{array}{l}8,2 \\
-\end{array}$ & $\begin{array}{l}4,53 \\
\text { r.n. }\end{array}$ \\
\hline \multicolumn{4}{|l|}{ Średnio - Mean } & 26,4 & 26,9 & 8,2 & \\
\hline
\end{tabular}




\begin{tabular}{l|c|c|c|c|c|c|c}
\hline \multicolumn{1}{c|}{1} & 2 & 3 & 4 & 5 & 6 & 7 & 8 \\
\hline $\begin{array}{l}\text { Mączniak prawdziwy zbóż i traw } \\
\text { Blumeria graminis }\end{array}$ & $\begin{array}{c}\text { liść } \\
\text { leaf }\end{array}$ & $\begin{array}{c}2005 \\
2006\end{array}$ & 75 & - & 2,3 & 0,0 & 0,88 \\
r.n.
\end{tabular}

r.n. - różnice nieistotne - not significant differences

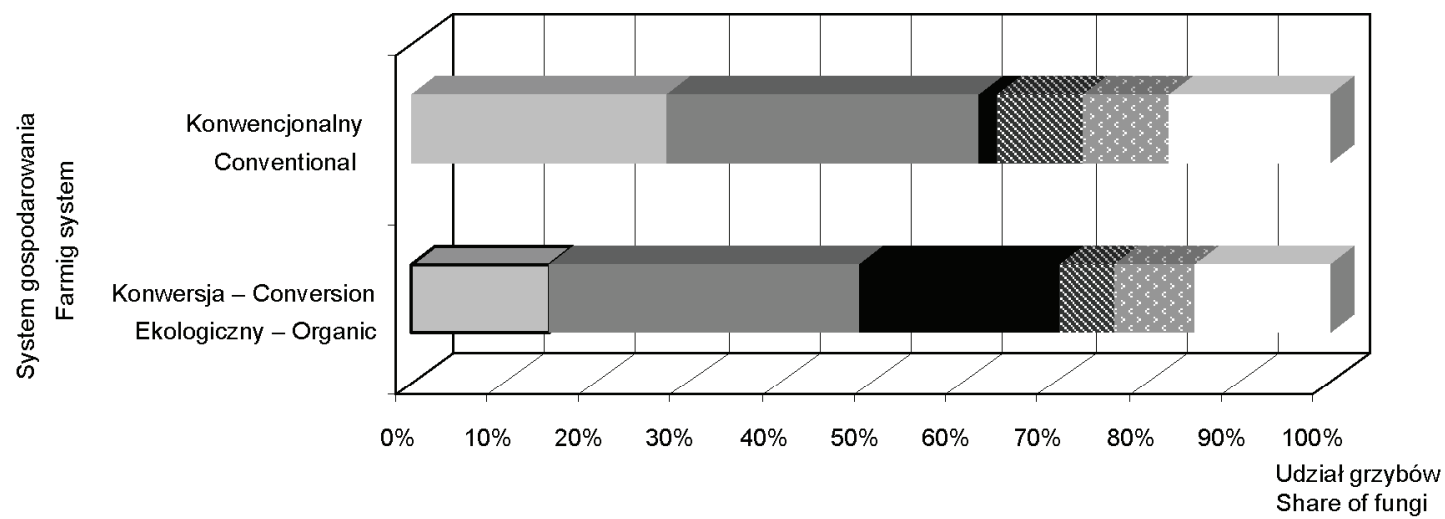

$\square$ Aureobasidium/Microdochium spp.

$\square$ Fusarium spp.

- Cochliobolus sativus

Gaeumannomyces graminis i inne patogeny - G. graminis and other pathogens

Grzyby antagonistyczne - Antagonistic fungi

$\square$ Inne - Other

Rys. 1. Grzyby dominujące izolowane z podstawy źdźbła jęczmienia jarego, 2004-2006

Fig. 1. Dominant fungi isolated from steam base sprig barley, 2004-2006

Zgodnie z wcześniejszymi doniesieniami (Lipa 1999; Baturo i wsp. 2004) również w toku badań własnych na liściach jęczmienia jarego odnotowano występowanie Rhynchosporium secalis, Pyrenophora teres oraz Blumeria graminis. Przebieg pogody w 2004 roku był przyczyną braku porażenia liści jęczmienia jarego przez patogeny, natomiast warunki panujące w 2006 roku sprzyjały rozwojowi chorób. W najwyższym nasileniu stwierdzono symptomy plamistości siatkowej. W obu systemach uprawy najlepsze warunki rozwoju $P$. teres miał w 2006 roku, gdy uzyskano najwyższe wartości Ip (indeksu porażenia w \%) - 26,4 i 35,3 odpowiednio w systemie ekologicznym i konwencjonalnym. Etap konwersji cechowała niska wartość Ip - 1,7\% (tab. 1). Rośliny uprawiane w systemie konwencjonalnym były nieznacznie silniej porażone przez $P$. teres. Przeciwną zależność prezentowano w badaniach Boligłowy i Klimy (2009), gdzie wykazano, że uprawa jęczmienia metodą ekologiczną $\mathrm{w}$ odniesieniu do konwencjonalnej stymulowała wzrost symptomów plamistości siatkowej.

Objawy rynchosporiozy obserwowano w 2005 i 2006 roku i Ip nie przekraczał 5,7\% w uprawie konwencjonalnej. W najniższym nasileniu objawy rynchosporiozy wystapiły na roślinach uprawianych w kierunku przestawiania produkcji konwencjonalnej na ekologiczna - 1,7\%. W 2005 roku symptomy mączniaka prawdziwego zbóż i traw wystapily tylko w konwencjonalnym systemie gospodarowania, a Ip wynosiły średnio $2,3 \%$. W kolejnym 
roku monitoringu zdrowotności jęczmienia porażenie liści przez B. graminis odnotowano w obu systemach gospodarowania i było ono wyższe niż w roku poprzedzającym. Średnio Ip przez mączniaka prawdziwego zbóż i traw był wyższy w ekologicznym systemie gospodarowania $(17,9 \%)$ w porównaniu do konwencjonalnego (4,6\%). W badaniach Błażej i Błażej (2000) dowiedziono, że występowanie chorób jęczmienia powodowanych przez $P$. graminea, $P$. teres i $R$. secalis uzależnione było głównie od warunków atmosferycznych, a w mniejszym stopniu od technologii uprawy. Przeciwnie, zdrowotność podstawy źdźbła jęczmienia jarego zależała od poziomu agrotechniki; im był on niższy, tym gorsza była zdrowotność.

$\mathrm{Na}$ podstawie źdźbła jęczmienia jarego corocznie w obu systemach gospodarowania notowano występowanie fuzaryjnej zgorzeli podstawy źdźbła (Fusarium spp.) oraz łamliwości źdźbła zbóż (Tapesia yallundae) (tab. 1). W drugim roku obserwacji w systemie konwencjonalnej uprawy jęczmienia odnotowano także rośliny z typowymi objawami zgorzeli podstawy źdźbła (Gaeumannomyces graminis). Symptomy fuzaryjnej zgorzeli podstawy źdźbła w pierwszym i ostatnim roku badań rozwinęły się w wysokim nasileniu. Najniższy udział roślin porażonych przez grzyby rodzaju Fusarium w całym okresie badań odnotowano w 2005 roku, gdy Ip nie przekraczał 21,0\%. Istotne różnice $\mathrm{w}$ nasileniu infekcji roślin odnotowano tylko w 2005 roku, gdzie na etapie konwersji występowanie fuzaryjnej zgorzeli podstawy źdźbła było zdecydowanie niższe $\mathrm{w}$ porównaniu $\mathrm{z}$ innymi obiektami. Wiadomo, że pozostające na polu resztki roślinne i większa wilgotność gleby wraz $\mathrm{z}$ notowaniem niskiej temperatury sprzyjają występowaniu chorób podstawy źdźbła i korzeni (Bailey i Lazarovits 2003). Występowanie łamliwości źdźbła zbóż i traw w poszczególnych latach było zróżnicowane. T. yallundae najsilniej opanowała jęczmień jary w 2004 roku, w którym najwyższy indeks porażenia stwierdzono w ekologicznej uprawie i osiagnął on średnią wartość 31,7\%. Najniższe nasilenie łamliwości źdźbła zbóż i traw odnotowano w 2005 roku, gdy indeks porażenia nie przekraczał 4,0\%. W ekologicznym systemie produkcji jęczmienia Ip wyniósł $12 \%$.

Uzyskane wyniki obserwacji polowych korespondują z ilościowym i jakościowym składem grzybów izolowanych $\mathrm{z}$ podstawy źdźbła jęczmienia jarego. Z wykazujących objawy chorobowe organów jęczmienia wyosobniono ogółem 198 kolonii grzybów, w tym 101 izolatów należących do 12 taksonów z podstaw źdźbła jęczmienia uprawianego według zasad rolnictwa ekologicznego oraz na etapie konwersji i 97 należących do 15 taksonów z jęczmienia uprawianego według zasad rolnictwa konwencjonalnego (rys. 1). Najliczniejszą grupę stanowiły grzyby rodzaju Fusarium (33,8\% wszystkich wyosobnień w systemie ekologicznym i konwersji oraz 33,9\% w konwencjonalnym). Wśród nich dominowało $F$. avenaceum (odpowiednio 22,8\% i 13,4\%), w konwencjonalnym systemie stosunkowo licznie izolowano również $F$. chlamydosporum (11,3\%). Pozostałe grzyby rodzaju Fusarium w systemie ekologicznym reprezentowały: $F$. culmorum, $F$. poae, $F$. verticillioides, a w konwencjonalnym: $F$. oxysporum, F. sacchari.

Wśród innych gatunków grzybów uznawanych za groźne patogeny zbóż stwierdzono także: Cochliobolus sativus oraz Gaeumannomyces graminis. C. sativus zdecydowanie częściej izolowano z podstaw źdźbeł jęczmienia uprawianego według zasad rolnictwa ekologicznego, gdzie stanowił 21,8\% wszystkich uzyskanych w tym systemie kolonii, podczas gdy w konwencjonalnej uprawie zaledwie 2,1\% (rys. 1), co potwierdzają badania Kurowskiego i wsp. (2012). G. graminis częściej izolowano z konwencjonalnego systemu gospodarowania (odpowiednio 9,3 i 5,9\%). Stosunkowo licznie izolowano także gatunki grzybów o niskim potencjale patogenicznym względem zbóż - Microdochium bolleyi i Aureobasidium pullulans. W systemie ekologicznym stanowiły one 14,9\% wszystkich wyosobnień, a w konwencjonalnym 27,8\%. Wśród grzybów, którym przypisuje się uzdolnienia antagonistyczne w stosunku do patogenów, wystapiły grzyby rodzaju Penicillium, które stanowiły 8,9\% wszystkich izolatów w systemie o profilu ekologicznym i 9,3\% w systemie konwencjonalnym. Podobne wyniki analiz mikologicznych ziarniaków jęczmienia $\mathrm{w}$ różnych rejonach uprawy zbóż uzyskali Błaszkowski i Piech (2002), Turkington i wsp. (2002) oraz Fakhrunnisa i wsp. (2006).

\section{Wnioski / Conclusions}

1. Okres konwersji wpływa inhibicyjnie na nasilenie chorób liści jęczmienia jarego.

2. Fuzaryjna zgorzel podstawy źdźbła dominuje na podstawie źdźbła jęczmienia jarego w obu systemach uprawy.

3. Nasilenie łamliwości źdźbła zbóż jest wyższe w konwencjonalnym systemie uprawy w porównaniu do ekologicznego.

4. Grzyby rodzaju Fusarium dominują wśród izolatów z porażonych podstaw źdźbeł jęczmienia jarego.

5. C. sativus jest potencjalnym zagrożeniem ekologicznych upraw jęczmienia, zaś $G$. graminis, M. bolleyi i A. pullulans upraw konwencjonalnych.

\section{Literatura / References}

Bailey K., Lazarovits G. 2003. Suppressing soil-borne diseases with residue management and organic amendments. Soil Till. Res. 72: $169-180$.

Baturo A., Łukanowski A., Kuś J. 2004. Comparison of health status of winter wheat and spring barley grain cultivated in organic, integrated and conventional systems and monoculture. p. 128-132. First World Conference on Organic Seed: Challenges and Opportunities for Organic Agriculture and the Seed Industry FAO Headquarters. Rome, July 5-7, 2004, 193 pp.

Błaszkowski J., Piech M. 2002. Comparison of seed-borne fungal communities of naked and husked oats and barley. Phytopathol. Pol. 24: $73-76$. 
Błażej J., Błażej J. 2000. Wpływ technologii produkcji na zdrowotność jęczmienia jarego i owsa. Pam. Puł. 120: 23-30.

Boligłowa E., Klima K. 2009. Zdrowotność jęczmienia jarego w uprawie ekologicznej i konwencjonalnej. [Plant health of spring barley in ecological and conventional cultivation systems]. Prog. Plant Prot./Post. Ochr. Roślin 49 (1): 13-16.

Fakhrunnisa, Hashmi M.H., Ghaffar A. 2006. Seed-borne micoflora of wheat, sorghum and barley. Pak. J. Bot. 38 (1): $185-192$.

Hinfner K., Paap Z.S. 1964. Atlas chorób i szkodników zbóż i kukurydzy. PWRiL, Warszawa, 206 ss.

Kurowski T.P., Marks M., Kurowska A., Orzech K. 2005. Stan fitosanitarny i plonowanie jęczmienia jarego w zależności od systemu uprawy. Acta Agrobot. 58 (2): 335-346.

Lipa J.J. 1999. Nowoczesna ochrona zbóż. Pam. Puł., Materiały Konferencji, 114: 241-259.

Łacicowa B. 1970. Badanie szczepów Helminthosporium sorokinianum (= H. sativum) oraz odporności jęczmienia jarego na ten czynnik chorobotwórczy. Acta Mycol. 6 (2): 184-248.

Mackiewicz D., Drath I. 1972. Wpływ zmianowania na stopień porażenia pszenicy przez łamliwość źdźbeł oraz na jej plonowanie. Biul. Inst. Ochr. Roślin 54: 153-169.

Reinecke P., Fehrmann H. 1979. Rhizoctonia cerealis van der Hoven an Getreide in der Bundesrepublik Deutschland. Z. Pflanzenkr. Pflanzenschutz. 86 (3/4): 190-204.

Townsend G.R., Heuberger J.W. 1943. Methods for estimating losses caused by diseases in fungicide experiments. Plant Dis. Rep. 24: $340-343$

Turkington T.K., Clear R.M., Burnett P.A., Patrick S.K., Orr D.D., Xi K. 2002. Fungal plant pathogens infecting barley and wheat seed from Alberta, 1995-1997. Can. J. Plant Pathol. 24: 302-308.

Weber R., Hryńczuk B., Kita W. 2005. Wpływ przedplonu i sposobu uprawy roli na porażenie kilku odmian pszenicy ozimej przez grzyby powodujące choroby podstawy źdźbła. Pam. Puł. 139: 299-310. 